\title{
Fabrication and Characterization of a Dye-Sensitized Solar Cell using Natural Dye Extract of Rosella (Hibiscus sabdariffa L.) as Photosensitizer
}

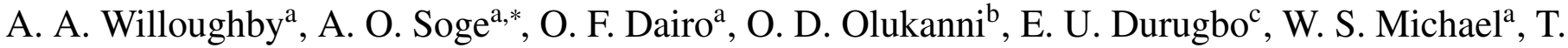 \\ A. Adebayo ${ }^{\mathrm{d}}$ \\ ${ }^{a}$ Redeemer's University, Faculty of Natural Science, Department of Physical Sciences, Gbongan-Osogbo Expressway, Akoda Ede, Osun State, Nigeria, 232102 \\ ${ }^{b}$ Redeemer's University, Faculty of Basic Medical Sciences, Department of Biochemistry, Gbongan-Osogbo Expressway, Akoda Ede, Osun State, Nigeria, 232102 \\ ${ }^{c}$ Redeemer's University, Faculty of Natural Science, Department of Biological Sciences, Gbongan-Osogbo Expressway, Akoda Ede, Osun State, Nigeria, 232102 \\ ${ }^{d}$ Redeemer's University, Faculty of Natural Science, Department of Chemical Sciences, Gbongan-Osogbo Expressway, Akoda Ede, Osun State, Nigeria, 232102
}

\begin{abstract}
The relatively low energy conversion efficiency of dye-sensitized solar cells (DSSCs) is a key challenge hindering the commercialization of the solar cell. The photochemical performance of the dye used as a photosensitizer for the DSSC greatly determines the efficiency of the solar cell. This study demonstrates the suitability of dye extracted from rosella (Hibiscus sabdariffa L.) flowers as a photosensitizer for a DSSC. The natural dye was extracted using the acid water extraction method and was characterized using FTIR spectroscopy and UV-vis spectrophotometry.The absorption spectra of the dye were examined to determine the aptness of the dye as a photosensitizer inDSSCs. The IR absorption spectra of the extracted dye confirmed both amine and hydroxyl compounds as functional groups in the natural dye, which established the suitability of the dye as a photosensitizer in DSSCs.The UV-vis absorption spectra of the natural dye within the visible region illustrate that the aqueous extract from rosella flowers has stable absorption of visible light, thus validating the natural dye as a good candidate for photosensitizer in a DSSC. The fabricated DSSC delivered a short-circuit current of $5 \mu \mathrm{A}$ and an open-circuit voltage of $0.637 \mathrm{~V}$.
\end{abstract}

DOI: $10.46481 /$ jnsps. 2021.346

Keywords: dye-sensitized solar cells, rosella flowers, natural dye, energy conversion efficiency, photosensitizers, absorption spectra

Article History :

Received: 13 August 2021

Received in revised form: 24 September 2021

Accepted for publication: 25 September 2021

Published: 29 November 2021

(C)2021 Journal of the Nigerian Society of Physical Sciences. All rights reserved. Communicated by: E. Etim

\section{Introduction}

Renewable energy sources can meet the growing energy demand and are poised to supply the world with a reliable, environmentally friendly, and sustainable energy system [1]. Dyesensitized solar cells (DSSCs), being a type of photovoltaic

\footnotetext{
${ }^{*}$ Corresponding author tel. no: +2347069381694

Email address: sogea@run.edu.ng, ayosoge@gmail.com (A. O.
} Soge )
(PV) device, have gained widespread attention in recent years due to their comparative advantages over silicon PV cells easy fabrication procedures, low manufacturing cost, and compatibility with flexible substrates [2]. Besides, DSSCs have a high potential for industrial-scale manufacturing due to their production using established scalable manufacturing methods $[3,4,5,6,7]$. Additionally, DSSCs display higher performance under low- and indoor-light conditions than the other PV technologies [8]. The expanded option of designing DSSCs using 
various materials coupled with flexibility in shape, colours, and transparency, has qualified DSSCs for potential applications in $\mathrm{PV}$ windows and textiles $[5,9,10]$.

The low photoelectric conversion efficiency and instability of the solar cells have been identified as the major challenges impeding the commercialization of DSSCs [8]. Although the highest theoretical efficiency for DSSCs has been calculated to be $32 \%$ [11], the maximum efficiency reported in the literature is about $14.3 \%$ as measured by Kakiage et al. in 2015 [12].

The authors utilized carboxy-anchor organic dye (LEG4) and alkoxysilyl-anchor dye (ADEKA-1) as co-sensitizers for the photoelectrodes together with a cobalt-based electrolyte in fabricating the devices [12]. Extensive research is being undertaken to investigate the factors that regulate the performance of DSSC to ultimately enhance its efficiency [2]. For instance, research interests in this field have focussed on optimizing the redox couple [13] and dye absorbance [14], modifying semiconductors with a wide band-gap as photo-electrodes $[15,16]$ and developing high-performance counter-electrodes [17].

Moreover, natural and commercial synthetic dyes have been reported as a good replacement for transition metal coordination compounds (rutheniumpolypyridyl complexes) which are regarded as effective sensitizers but contain a costly heavy metal that posed environmental challenges [18]. Besides, the process of synthesizing the complexes is complicated and expensive [19]. The advantages of natural dyes include their abundance in nature, environmental friendliness, and affordability.On the other hand, synthetic organic dyes, such as coumarin, xanthene, phthalocyanine, and cyanine dyes exhibit poor performance in DSSCs owing to weak anchorage with $\mathrm{TiO}_{2}$ film and low UVvis absorption capability [2]. However, these synthetic organic dyes are inexpensive and easy to prepare [20].

The energy conversion efficiency of a DSSC is determined mainly by the absorption spectrum of the dye couple with its anchorage to the $\mathrm{TiO}_{2}$ surface [21]. Hence, the dye used as a sensitizer in a DSSC plays a prominent role in the performance of the solar cell [19]. To improve the performance of DSSCs with natural dye as a sensitizer, several researchers have investigated a wide variety of plants, fruits, and flowers to determine their effectiveness as sensitizers in DSSCs. For instance, Sudhakaret et al. [22] fabricated DSSCs using extracted dye from Bauhinia purpurea $L$. flower as a sensitizer. According to the experimental results, the as-prepared solar cells delivered a conversion efficiency of $0.63 \%$, with an open-circuit voltage of 0.7 $\mathrm{V}$, short-circuit current density of $1.4 \mathrm{~mA} / \mathrm{cm}^{2}$, and a fill factor of $0.64 \%$.

Reda et al. [23] investigated anthocyanin extracts from mulberry (Morus alba L.) fruit and Akenchira (Striga hermonthica(Delile) Benth.) flower as natural photosensitizers with a $\mathrm{TiO}_{2}$ semiconductor. Anthocyanin raw pigments extracted from M. alba fruits and S. hermonthicaflowers under acidic conditions delivered incident photon to current conversion efficien- cies (IPCEs) greater than 15\%. However, both the IPCEs and solar energy conversion efficiency of the DSSCs were enhanced using acidified ethanol for dye extraction. The IPCEs obtained for the dye extracted from $M$. alba and S. hermonthica were $27 \%$ and $17 \%$, respectively, while conversion efficiencies of the DSSCs fabricated using dyes extracted from M. alba and S. hermonthica were $0.420 \%$ and $0.304 \%$, respectively.

Abdou et al. [19] compared the performance of DSSCs fabricated using three different dyes as photosensitizers - rosella (Hibiscus sabdariffa L.) flowers, Remazole Red RB-133, and merocyanin-like dye-based on 7-methyl coumarin. The highest conversion efficiency of $0.27 \%$ was obtained with the natural dye extracted from rosella flowers. Remazole Red RB-133 and merocyanin-like dye delivered lower conversion efficiencies of $0.14 \%$ and $0.001 \%$, respectively. Additionally, Senthil et al. [24] investigated the photochemical characteristics of two natural dyes extracted from Eugenia jambolana $L$. and Delonix regia and reported efficiencies of $0.55 \%$ and $0.317 \%$, respectively. In a similar study, Chang and Lo [25] prepared DSSCs using dyes extracted from pomegranate leaves and mulberry fruits as photosensitizers. The DSSCs fabricated with the dye mixture delivered the best conversion efficiency of $0.722 \%$ while those of pomegranate leaves and mulberry fruits offered relatively lower conversion efficiencies of $0.597 \%$ and $0.548 \%$, respectively.

Gomez-Ortiz et al. [26] prepared solar cells using $\mathrm{TiO}_{2}$ and $\mathrm{ZnO}$ nanostructured, mesoporous films sensitized with annatto, bixin, and norbixin dyes extracted from achiote seeds (Bixaorellana L.). Best results were obtained for bixin-sensitized $\mathrm{TiO}_{2}$ solar cell with conversion efficiency up to $0.53 \%$. This study investigates the performance of rosella (Hibiscus sabdariffa $L$.) as a photosensitizer in a DSSC. Additionally, the IR and UV-vis absorption spectra of the natural dye are examined to validate the suitability of the dye as a photosensitizer in the fabrication of a DSSC.

\section{Materials and methods}

Dye was extracted from rosella (H. sabdariffa) flowers (Figure 1) using the acid water $\left(\mathrm{H}_{2} \mathrm{SO}_{4}\right)$ extraction method.

\subsection{Preparation}

The dye extract was prepared by grinding $12 \mathrm{~g}$ of dried rosella flowers in $500 \mathrm{ml}$ of acid water with $\mathrm{pH}=5.7$. The extract was filtered and centrifuged separately to remove any solid residue and stabilized at $\mathrm{pH}=5.7$ by adding an aqueous solution of $0.1 \mathrm{M} \mathrm{HCl}$. The half-time deactivation of the dye solution was over 12 months provided they are correctly stored at $4{ }^{\circ} \mathrm{C}$ in a refrigerator [27]. The natural dye extracted from the rosella flowers was characterized using T60 UV-vis spectrophotometer (PG electronics, UK) by measuring their UV absorbance. Additionally, a Fourier transform infrared (FTIR) spectroscopy analysis was carried out on the natural dye to determine its chemical compositions using FTIR-8400S spectrophotometer (Shimadzu Scientific Instruments Inc., Japan). 


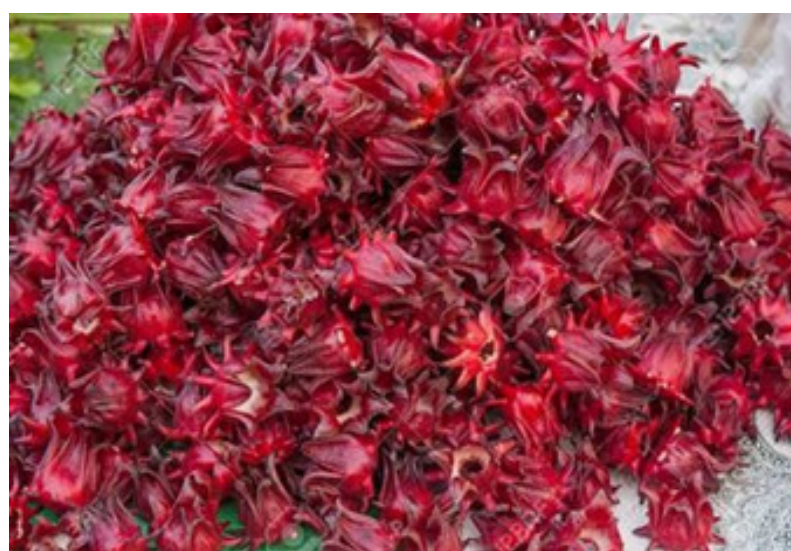

Figure 1: Rosella (H. sabdariffa) flowers .

The fabrication of DSSCs normally involves using materials with properties that typically increase the performance and efficiency of the cells. This includes a porous film of nanocrystalline semiconductor such as titanium dioxide film, an electrolyte, dye sensitizers, and conductive glasses as electrodes.

The electrolyte was prepared using $10 \mathrm{ml}$ ethylene glycol, $0.127 \mathrm{~g}$ iodine, and $0.83 \mathrm{~g}$ potassium iodide. The electrolyte solution was stirred thoroughly until no grains of iodine and potassium iodide were visible. The photo-anode comprising fluorine-doped tin oxide glass substrates annealed with a porous $\mathrm{TiO}_{2}$ was synthesized by absorbing a small amount of the dye extract on the $\mathrm{TiO}_{2}$ layer. The electrode was left for about 10 minutes for complete absorption of the dye, then rinsed first using deionized water and then a final rinse with ethanol (which acts as a drying agent to remove any present water). Afterward, the film was dried in an oven at $60^{\circ} \mathrm{C}$ for 5 minutes. With this approach, the dye extends the photoanode's spectral sensitivity, thereby enabling the collection of lower energy photons. The counter-electrode (or cathode) was prepared by coating the conductive side of the fluorine-doped tin oxide glass with graphite after wiping the surface with ethanol. The DSSC was assembled by placing the $\mathrm{TiO}_{2}$-coated anode facing upward, and the conductive side of the graphite-coated cathode faced the $\mathrm{TiO}_{2}$ film. The electrodes were positioned slightly offset to allow enough space for electrical contacts and were held together using binder clips, as shown in Figure 2. The electrolyte was introduced into the space between the electrodes by capillary action.

The open-circuit voltage and short-circuit current of the fabricated DSSCs were determined under a laboratory condition using a multimeter with a flash lamp (CTL - RL020) with an intensity less than $100 \mathrm{~mW} / \mathrm{cm}^{2}$ illumination.

\section{Results and discussion}

The FTIR result showing the infrared (IR) spectra of the extracted dye from rosella flowers is presented in Figure 3. A broad absorption typical of the hydroxyl group was observed at

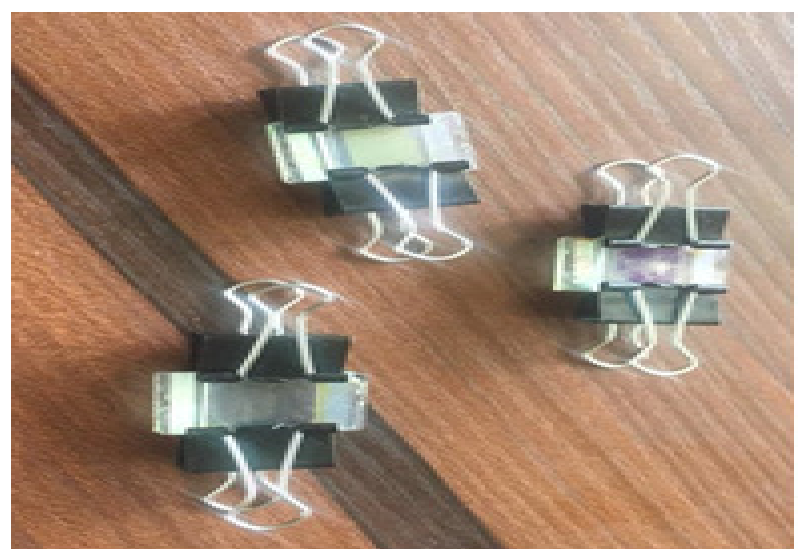

Figure 2: Assembled dye-sensitized solar cells showing the electrodes being held together with binder clips.

$3421.83 \mathrm{~nm}$ for the natural dye. The second absorption band was detected at $2359.02 \mathrm{~nm}$ (Figure 3). This relatively narrow absorption is attributed to the $\mathrm{C}-\mathrm{H}$ stretch of a terminal alkyne or acetylenic compound. Additionally, the prominent absorption band for the dye at $\sim 3430 \mathrm{~nm}$ is broad and indicates the presence of hydroxyl and $\mathrm{N}-\mathrm{H}$ amine/amide groups. Furthermore, the results show the presence of amide I (1600$\left.1800 \mathrm{~cm}^{-1}\right)$ and amide II $\left(1470-1570 \mathrm{~cm}^{-1}\right)$ groups. Amide I groups are products of $\mathrm{C}-\mathrm{O}$ bonds while amide II groups are associated with $\mathrm{N}-\mathrm{H}$ bending typically of amino acids. Amino acids are protein constituent which functional groups readily increase electron transfer process in DSSC layer. They achieve this by acting as acids in strong bases (donating protons) and as bases (accepting protons from strong acids) [28]. Thus, the IR spectra of the extracted dye confirmed the presence of amine and hydroxyl groups in the natural dye which implies that the dye is a suitable photosensitizer for DSSCs.

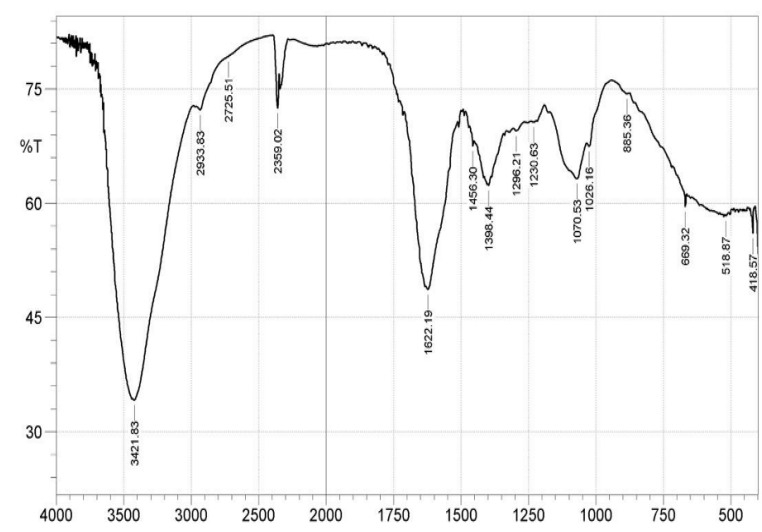

Figure 3: Infra-red spectra of the extracted dye from rosella (H. Sabdariffa) flowers showing the IR transmission percentage $(\% \mathrm{~T})$ versus wavelength in $\mathrm{nm}$.

The UV-vis absorption spectra for the aqueous extract of rosella (H. Sabdariffa) flowers are illustrated in Figure 4.

Absorbance is a measure of UV light absorbed by the dye. The higher the value, the more a particular wavelength is being absorbed. Many organic compounds undergo electronic 


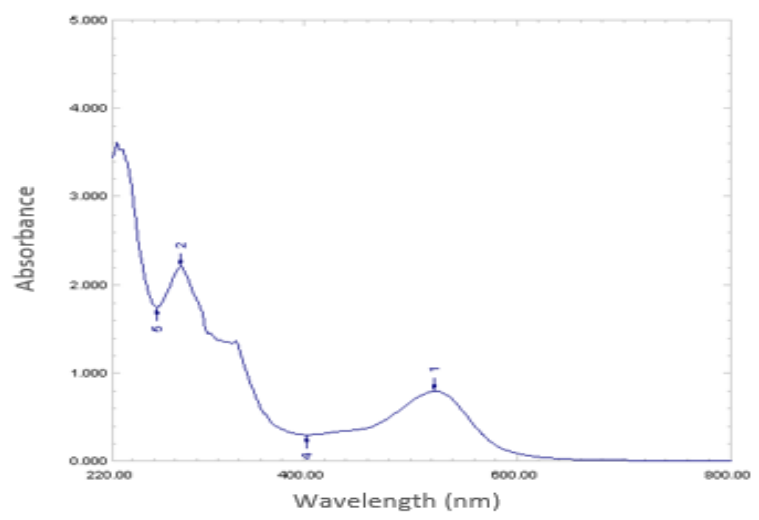

Figure 4: UV-vis absorption spectra of rosella (H. sabdariffa) flowers .

changes owing to shorter wavelengths and higher energy radiation in the UV (200-400 $\mathrm{nm})$ and visible $(380-800 \mathrm{~nm})$ ranges of the electromagnetic spectrum [29]. The purple colour of the dye extracted from rosella flowers $(H$. Sabdariffa) could be attributed to both the absorption peak at $520 \mathrm{~nm}$ lying within the green-cyan region $(500-565 \mathrm{~nm})$ and the absorption peaks at 230 and $290 \mathrm{~nm}$ falling within the UV region $(200-400 \mathrm{~nm})$. The UV-vis absorption spectra of the natural dye within the visible region $(380-800 \mathrm{~nm})$ illustrates that the aqueous extract from rosella flowers has stable absorption of visible light, implying that the dye is a good candidate for photosensitizer in DSSCs.

Moreover, the fabricated DSSC with the natural dye extracted from rosella flowers as a photosensitizer, demonstrated promising photoelectrochemical performances delivering shortcircuit current of $5 \mu \mathrm{A}$ and an open-circuit voltage of $0.637 \mathrm{~V}$ using a liquid-state electrolyte composed of PEO-ethylene glycol, iodine, potassium iodide blend.

\section{Conclusion}

This work reports an investigation on the suitability of the natural dye extracted from rosella $(H$. sabdariffa) flowers as a photosensitizer in a DSSC. The IR spectra of the extracted dye confirmed both amine and hydroxyl groups in the natural dye suggesting that the dye is a suitable photosensitizer for DSSCs. The UV-vis absorption spectra of the natural dye within the visible region $(380-800 \mathrm{~nm})$ demonstrate that the dye extracted from rosella flowers has stable absorption of visible light, indicating that the natural dye is a good candidate for photosensitizer in a DSSC. The fabricated DSSC with the aqueous extract of rosella flowers as photosensitizer displayed promising photoelectrochemical performances delivering short-circuit current of $5 \mu \mathrm{A}$ and an open-circuit voltage of $0.637 \mathrm{~V}$.

\section{References}

[1] M. S. Su'ait, M. Y. A. Rahman \& A. Ahmad, "Review on polymer electrolyte in dye-sensitized solar cells (DSSCs)", Solar Energy 115 (2015) 452.
[2] S. Mozaffari, M. R. Nateghi \& M. B. Zarandi, "An overview of the Challenges in the commercialization of dye sensitized solar cells", Renewable and Sustainable Energy Reviews 71 (2017) 675.

[3] H. Iftikhar, G. G. Sonai, S. G. Hashmi, A. F. Nogueira \& P. D. Lund, "Progress on electrolytes development in dye-sensitized solar cells", Materials 12 (2019) 1998.

[4] F. Bittner, T. Oekermann \& M. Wark, "Scale-up of the electrodeposition of $\mathrm{ZnO} /$ Eosin $\mathrm{Y}$ hybrid thin films for the fabrication of flexible dyesensitized solar cell modules", Materials 11 (2018) 232.

[5] I. Juhász Junger, D. Wehlage, R. Böttjer, T. Grothe, L. Juhász, C. Grassmann, T. Blachowicz \& A. Ehrmann, "Dye-sensitized solar cells with electrospun nanofiber mat-based counter electrodes", Materials 11 (2018) 604.

[6] S. Hashmi, D. Martineau, X. Li, M. Ozkan, A. Tiihonen, M. Dar, T. Sarikka, S. Zakeeruddin, J. Paltakari, P. Lund and et al., "Air Processed Inkjet Infiltrated Carbon Based Printed Perovskite Solar Cells with High Stability and Reproducibility", Adv. Mater. Technol. 2 (2017) 1600183.

[7] S. Hashmi, M. Ozkan, J. Halme, K. Misic, S. Zakeeruddin, J. Paltakari, M. Grätzel \& P. Lund, "High performance dye-sensitized solar cells with inkjet printed ionic liquid electrolyte", Nano Energy 17 (2015) 206.

[8] A. Fakharuddin, R. Jose, T. M. Brown, F. Fabregat-Santiago \& J. Bisquert, "A perspective on the production of dye-sensitized solar modules", Energy \& Environmental Science 7 (2014) 3952.

[9] D. S. Lim, K. W. Park, A. A. Wiles \& J. Hong, "Metal-free organic chromophores featuring an ethynyl-thienothiophene linker with an n-hexyl chain for translucent dye-sensitized solar cells", Materials 12 (2019) 1741.

[10] A. Hagfeldt, G. Boschloo, L. Sun, L. Kloo \& H. Pettersson, "Dyesensitized solar cells", Chemical reviews 110 (2010) 6595.

[11] H. J. Snaith, "Estimating the maximum attainable efficiency in dyesensitized solar cells", Adv. Funct. Mater. 20 (2010) 13.

[12] K. Kakiage, Y. Aoyama, T. Yano, K. Oya, J. I. Fujisawa \& M. Hanaya, "Highly-efficient dye-sensitized solar cells with collaborative sensitization by silyl-anchor and carboxy-anchor dyes", Chemical communications 51 (2015) 15894.

[13] J. Wu, Z. Lan, J. Lin, M. Huang, Y. Huang, L. Fan \& G. Luo, "Electrolytes in dye-sensitized solar cells", Chemical reviews 115 (2015) 2136.

[14] B. Sebo, N. Huang, Y. Liu, Q. Tai, L. Liang, H. Hu, S. Xu \& X. Z. Zhao, "Dye-sensitized solar cells enhanced by optical absorption, mediated by $\mathrm{TiO}_{2}$ nanofibers and plasmonics Ag nanoparticles", Electrochimica Acta 112 (2013) 458.

[15] J. Macaira, L. Andrade \& A. Mendes, "Review on nanostructured photoelectrodes for next generation dye-sensitized solar cells", Renewable and Sustainable Energy Review 27 (2013) 334.

[16] R. C. C. \& R. Prasanth, "A critical review of recent developments in nanomaterials for photoelectrodes in dye sensitized solar cells", Journal of Power Sources 317 (2016) 120

[17] M. Wu \& T. Ma, "Platinum-free catalysts as counter electrodes in dyesensitized solar cells", Chem. Sus. Chem. 5 (2012) 1343.

[18] Y. Amao \& T. Komori, "Bio-photovoltaic conversion device using chlorine-e6 derived from chlorophyll from Spirulina adsorbed on a nanocrystalline $\mathrm{TiO}_{2}$ film electrode", Biosensors and Bioelectronics 19 (2004) 843.

[19] E. M. Abdou, H. S. Hafez, E. Bakir \& M. S. A. Abdel-Mottaleb, "Photostability of low cost dye-sensitized solar cells based on natural and synthetic dyes", Spectrochimica Acta Part A: Molecular and Biomolecular Spectroscopy 115 (2013) 202.

[20] S. Hao, J. Wu, Y. Huang \& J. Lin, "Natural dyes as photosensitizers for dye-sensitized solar cell”, Solar energy 80 (2006) 209.

[21] K. Tennakone, G. Kumara, A. Kumarasinghe, P. Sirimanne \& K. Wijayantha, "Efficient photosensitization of nanocrystalline $\mathrm{TiO}_{2}$ films by tannins and related phenolic substances", J. Photoch. Photobio. 94 (1996) A94.

[22] C. Sudhakar, T. Selvankumar, K. Selvam \& M. Govindaraju, "Bauhinia purpurea $L$. flower mediated dye used as sensitizers for $\mathrm{TiO}_{2}$ based dyesensitized solar cells", International Journal on Advanced Science, Engineering 2 (2016) 209.

[23] A. Reda, S. Tadesse \& T. Yohannes, "Dye-sensitized solar cell using natural dyes extracted from Morus atba Lam fruit and Striga hermonthica flower", Journal of Photonics for Energy 4 (2014) 043091.

[24] T. S. Senthil, M. Thambidurai, N. Muthukumarasamy, R. Balasundara- 
prabhu \& S. Agilan, "Preparation and Characterization of Sol-Gel Spin Coated Nanocrystalline $\mathrm{TiO}_{2}$ Films", Advanced Science Letters 4 (2011) 3649.

[25] H. Chang \& Y. J. Lo, "Pomegranate leaves and mulberry fruit as natural sensitizers for dye-sensitized solar cells", Solar energy 84 (2010) 1833.

[26] N. M. Gómez-Ortíz, I. A. Vázquez-Maldonado, A. R. Pérez-Espadas, G. J. Mena-Rejón, J. A. Azamar-Barrios \& G. Oskam, "Dye-sensitized solar cells with natural dyes extracted from achiote seeds", Solar Energy Materials and Solar Cells 94 (2010) 40.

[27] A. R. Hernandez-Martinez, M. Estevez, S. Vargas, F. Quintanilla \& R. Rodriguez, "New dye-sensitized solar cells obtained from extracted bracts of
Bougainvillea glabra and spectabilis betalain pigments by different purification processes", International journal of molecular sciences 12 (2011) 5565.

[28] P. Trihutomo, S. Soeparman, D. Widhiyanuriyawan \& L. Yuliati, "Performance improvement of dye-sensitized solar cell-(DSSC-) based natural dyes by clathrin protein", International Journal of Photoenergy 2019 (2019) 1.

[29] Excited Electronic States: Electronic Spectroscopy of Molecules (3rd February 2016). https://chem.libretexts.org/@go/page/44497 (Accessed on 13th September 2021). 